\title{
大腿骨遠位端骨折の治療経験
}

\author{
博慈会記念病院 \\ 松 藤靖・西 辻一成 \\ 埜田和之・岡村明 \\ 田 中 裕 之・白 濱 正 博
}

\section{Clinical Experience of Distal Femoral Fractures}

by

\section{Yasushi Matsufuji, Kazunari Nishitsuji, Kazuyuki Noda, Akira Okamura, Hiroyuki Tanaka and Masahiro Shirahama}

Department of Orthopedic Surgery, Hakujikai Memorial Hospital, Tokyo, Japan

\begin{abstract}
In most cases, distal epiphyseal fracture of the femur turns out to be an intra-articular fracture. Com pounded with the knee joint contracture and other problems. it poses a difficult challenge even to today's advanced bone fracture treatment.

Briefly presented herein are therapeutic experiences on 17 such fractures encountered from January 1986 through November 1989.

Fifteen patients (nine males, six females : average age, 46.5 years) were studied. Bone fractures were classified in terms of Seinsheimer's classification and results evaluated with Neer's criteria.

Types I through III showed good results, even with surgical treatment. However, Type IV c was accompanied by knee joint contracture both at time of injury and after surgical intervention : thus, results were poor and justified secondary surgery.
\end{abstract}

\section{はじめに}

大腿骨遠位端骨折は，その大多数が関節内骨折とな

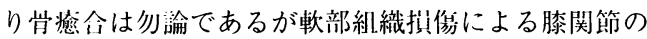
拘維などの䦌題を有し，肖折治燎法が進歩した現在で も淌その治䝤に難沙する班例が多い。

今回我々は本骨折を治療し若干の治療経験を得たの で報告する.

\section{対 象}

症例は 1986 年 1 月より 1989 年 11 月までに治療し た 15 例 17 骨折である. 性別は男性 9 例, 女性 6 例で, 年令は 16 歳から 78 歳平均 46.5 歳, 罹患側は右 4 例 左 9 例両側 2 例であった。 また開放骨折は 4 例 5 骨折 であった（表 1 )。

受傷機転は交通外傷が 11 例と最も多く合併症は
High Energy 外傷を反映して多発骨折が 9 例と半数以 上に認められた。

経過観察期間は, 3 力月から 2 年 6 力月平均 9 力月 であった。

\section{治 療 方 法}

常折の分類は Seinsheimer ${ }^{6)}$ の分類に従い部位に関 係なく $2 \mathrm{~mm}$ 以上の転位のないものをタイプ I 1 崮 折。顆䦌㿥に肖折線が及ばないものタイプII 5 肖折.

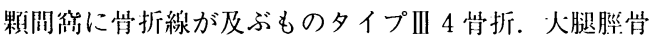
関節㧌に肖折線が及ぶものをタイプIV 7 肖折であっ た。

タイプIV Cが 6 例と最も多かった（図 1 ).

治療法は観血的治療を第一選択として行い, タイプ II に対してはA-O PLATE，タイプIIIに対しては CANCELLOUS SCREW，タイプIVに対しては顆部用 


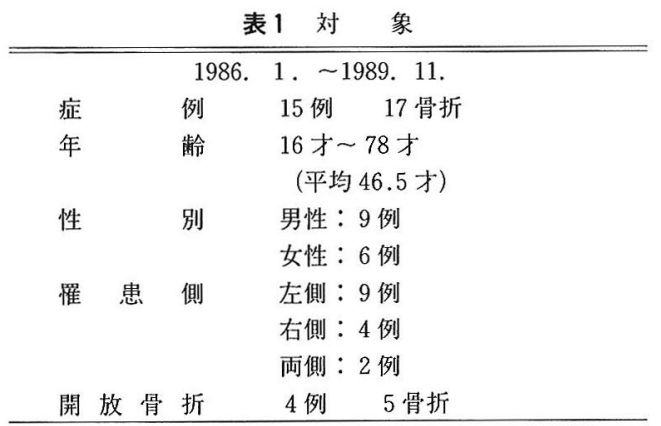
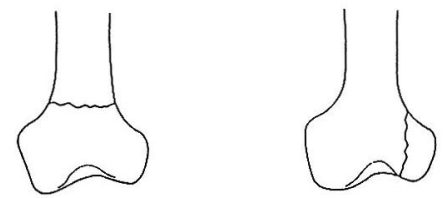

1 骨折

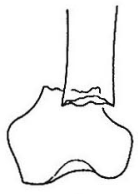

A

2 骨折

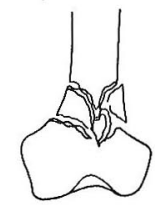

B

2 骨折

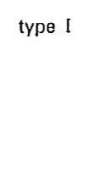

type II

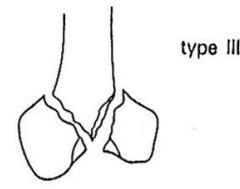

C

3 骨折
2 骨折

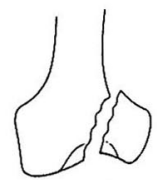

B

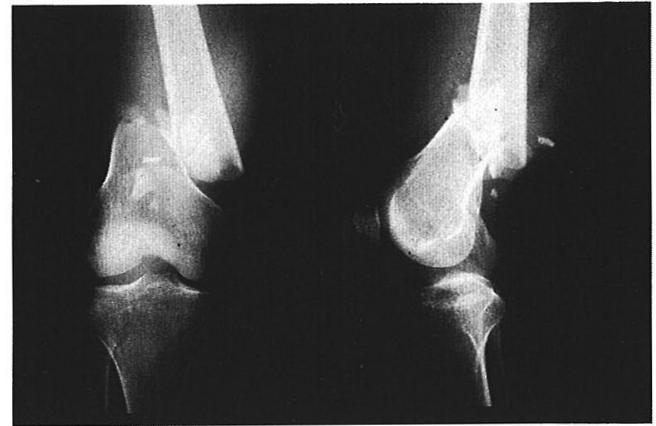

受傷時

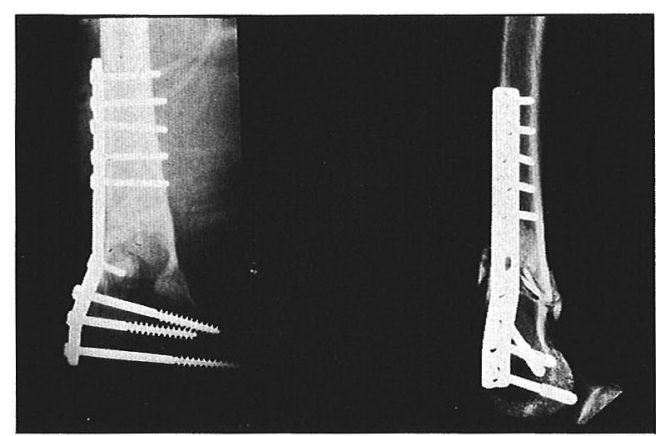

術後

図2 症例 $1: 50$ 才, 男性 右 type II A A-O PLATEにて骨接合施行し, 成績良好.

治㙩の成績判定は Neer ら ${ }^{5)}$ の評㑣表に従い，痛み， 歩行, 膝の動き, ADL, X 線評俹の 5 項目について 100 点満点で評倾した。

\section{結果}

成績はタイプIから而において良以上のほぼ満足す べき成績を得たがタイプ V C は 57 点と可であり満足 すべき成績は得られなかった（表 3 ).

タイプIV Cにおいて固定法による後療法期間および

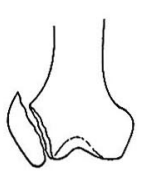

A

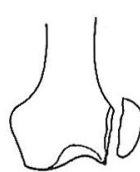

1 骨折

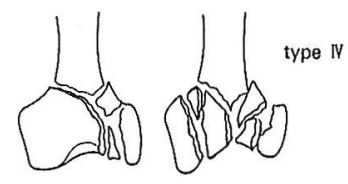

C

6 惯折
図1 Seinsheimer の分類

Tube Plate (以下 CCS と略す) を最も多く使用した（表 2).
成績を比較してみると, 早期より ROM 訓練を開始し た CCS と長期間外固定を行った Ender および Multiple pinning との間には成績の差は見られなかった（表 4 ).

\section{代表 的症例}

症例 $1 ： 50$ 墄, 男性.

交通事故にて受傷, 右タイプ II A, 腓骨神経麻瘁を 合併していたＡ-O PLATEにて骨接合術を施行した

(図 2 ). 成績は 94 点優であった. 


\begin{tabular}{|c|c|c|c|c|c|c|c|}
\hline Type & Ope & $\mathrm{CCS}$ & $\begin{array}{l}\text { cancellous. } \\
\text { screw }\end{array}$ & A-oplate & $\begin{array}{c}\text { multiple } \\
\text { pinning }\end{array}$ & Ender & 保存的 \\
\hline \multicolumn{2}{|l|}{ I } & & & & & & 1 \\
\hline \multirow{2}{*}{ II } & A & 1 & & 1 & & & \\
\hline & $\mathrm{B}$ & & & 2 & & & \\
\hline \multirow{3}{*}{ III } & $\mathrm{A}$ & & 2 & & & & \\
\hline & $\mathrm{B}$ & & & & & & \\
\hline & $C$ & 1 & 1 & & 1 & & \\
\hline \multirow{3}{*}{ IV } & A & & & & & & \\
\hline & B & & 1 & & & & \\
\hline & C & 4 & & & 1 & 1 & \\
\hline \multicolumn{2}{|c|}{ 計 } & 6 & 4 & 3 & 2 & 1 & 1 \\
\hline
\end{tabular}

表 3 治 療 成 績

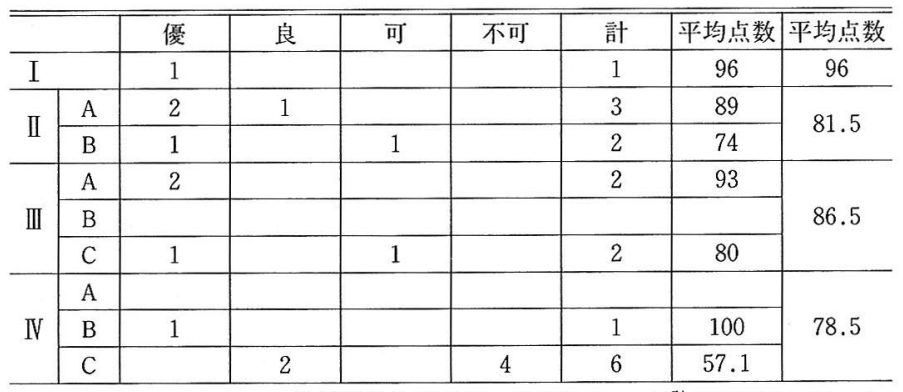

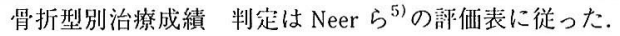

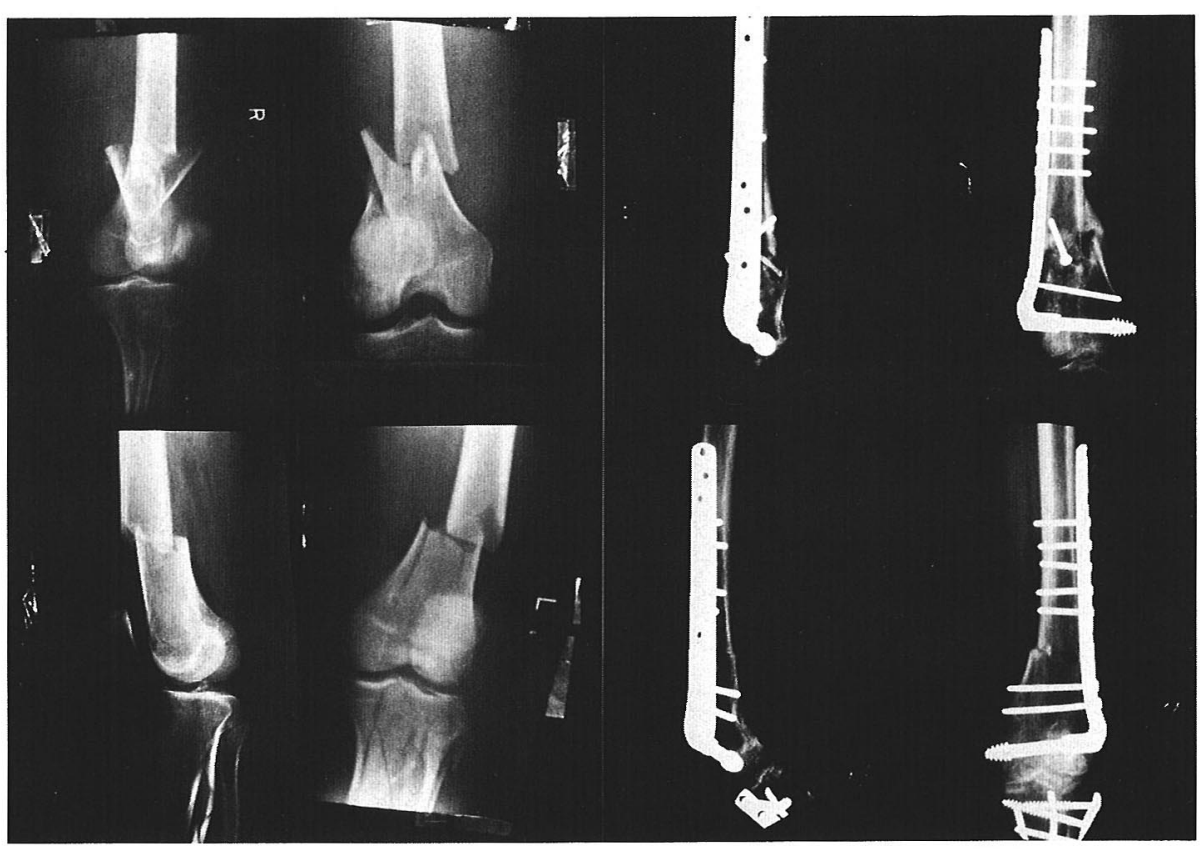

受傷時 術後

図 3 症例 $2: 54$ 才, 男性 画側 type N C 再側 CCSにて骨接合術施行寸るも成績不良. 


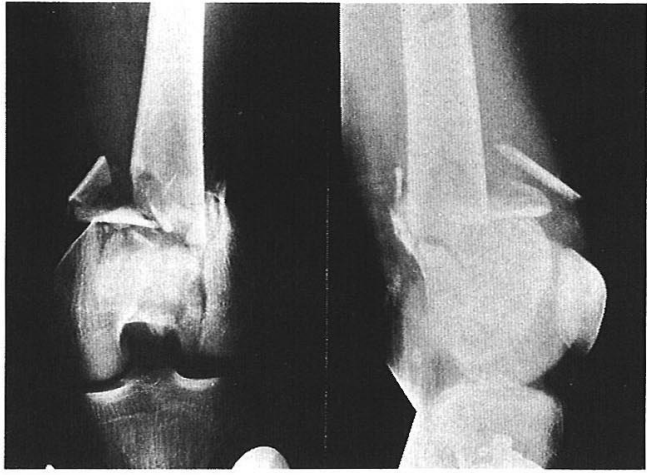

受傷時

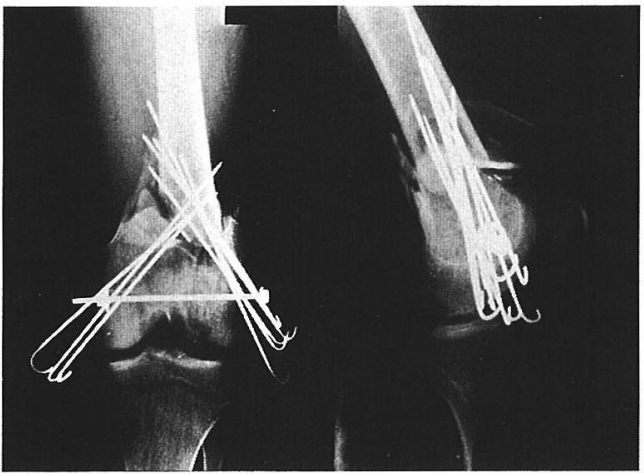

術後

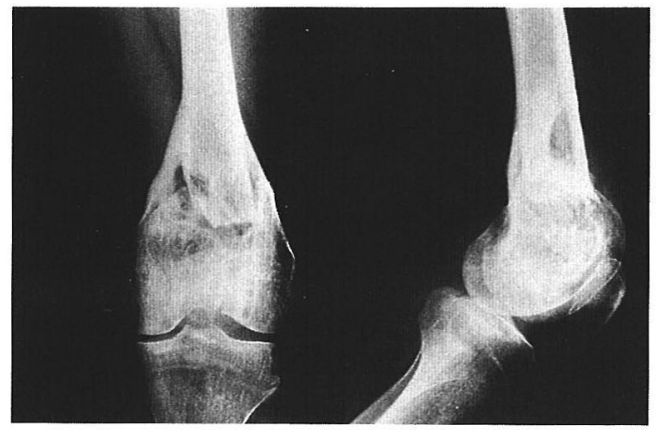

抜針術後

图 4 症例 3:19才, 男性 左 type IV C 術后膝関節狗縮に対し援動術にて成功した症例。

症例 $2 ： 54$ 歳，男性.

労災事故により受傷, 両側タイプIV C, 右下腿開放 骨折，右脛骨外顆骨折，右足関節外果骨折を合併して いた．両側 CCSにて骨接合術を施行したが（図 3) 成績は右 55 点不可, 左 54 点不可であった.

症例 $3: 19$ 歳, 男性.

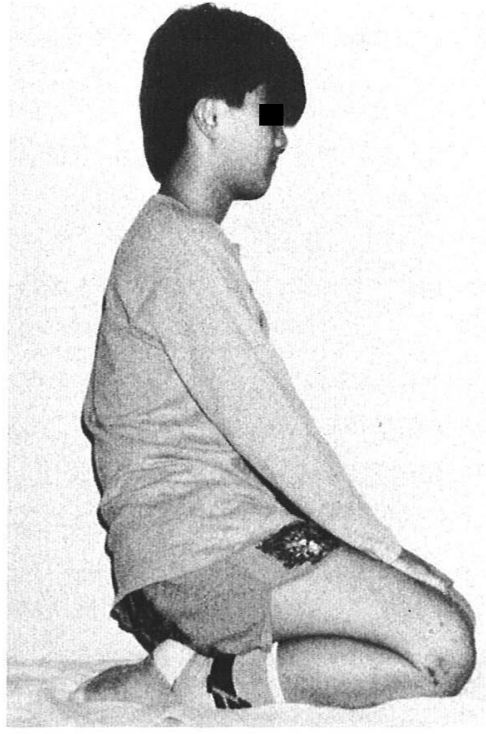

图 5 術後 8 カ月で授動術を行い正座可能となった

表 4 治療法による後療法期間の差

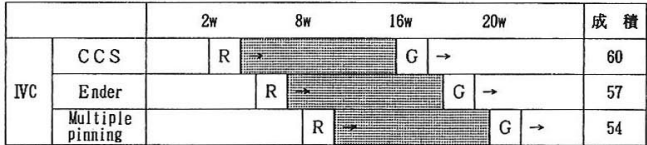

\begin{tabular}{|l|l|l|l|l|}
\hline 外固定 & & ROM & R & $\rightarrow$ \\
\hline 褺 具 & 全荷重 & G & $\rightarrow$ \\
\hline
\end{tabular}

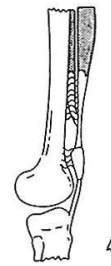

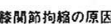

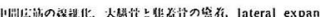

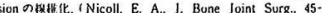
(183. (911. 19635.1)
Enneking：関節内に線䌖脂肪组機 们增殖。

滕蕫骨と大腿骨顆部の

恋着をきたす。

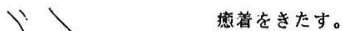

交通事故にて受傷，左タイプIV C, Tibia bolt, $\mathrm{K}$-wireにて骨接合術施行（図 4)。6カ月間リハビリ 後 ROM は $0^{\circ} \sim 90^{\circ}$ で成績は 58 点可であった. 8 カ 月後授動術を行い正座可能となり（図 5 ), 成績は 74 点良と改善した。 


\section{考察}

大腿常遠位端常折については諸家により多数の報告 がなされ保你的に治潦すべきか観血的にも呂い結果が 得られるか論議されてきた。 Watson-Jones ${ }^{8)}$, White らは镍血的治橑を, Bohler, Stewart ${ }^{7)}$, Neer $^{5)} ら$,

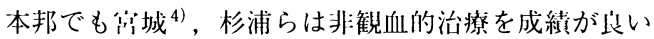
としている.

今回，我々は CCS により強固な内固定を行ったが 満足できる結果は得られなかった。成績不良の原因と して関節可動域の制限がある。此れは NICOL らが報 告するように受傷時の膝周囲軟部組織損傷および観血 的治療による瘏痕の助長によるものと考えられる（図 6 ). 本骨折タイプIV C に対して，膝関節機能をでき るだけ改善させるためには二次的手術を考慮しなけれ ばならないと思われた。

本骨折に対しては, むやみに観血的治療を行うので はなく膝関節機能をできるだけ温存させるために，保 存的治療を重視しなければならないことを痛感した。

\section{まと め}

1） 1986 年 1 月より 1989 年 11 月までに治療した 大腿骨遠位端骨折 15 例について報告した.

2) Type I から III は観血的な治療を行っても良好 な成績が得られた.

3） Type IV C は受傷時及び手術侵襲により膝関節 の拘縮をきたし成績が不良であり，二次的手術が必要 であると思われた。

\section{参 考 文 献}

1) 青柳孝一: Fractures of the distal Femur. Journal of Joint Surgery. Vol.8 No.4,1989.

2) 藤巻悦夫 : Joint-disorders due to the treatment of fractures of the lower extremity. Journal of Joint
Surgery. Vo7.8 No.5,1988.

3）桑野正：大腿骨遠位端骨折の治療. 整形・災害外科 $32,1347-1355,1989$.

4）宮城成圭：大腿骨下端部の骨折。 日整会誌 49,441-452, 1975 .

5) Neer, C.S. : Supracondylar fractures of the adult femur J.B.J.S., 49A, 591-613, 1967.

6) Seinshimer. F. III : Fractures of the distal femur 169,1980 .

7) Stewart, M.J. : Fractures of the distal third of the femur. J.B.J.S., 48A. 784-807,1966.

8) Watson-Jones : Fractures and Joint Injuries, Vol. II . 4th ed., 744-747, 1956.

9）横山一彦: 大腿骨顆上骨折の非観血的治療. 整形外 科. 37 巻 8 号, $37: 965-974,1986$.

質 問 福岡整形外科 徳永 純一

Seinsheimer 分類は一般的に引用されないが，あえ てこの分類を採用された理由は如何ですか.

回答博慈会記念病院 松藤 靖 大腿骨遠位端骨折の予後には関節泊の破壊状態が大 きく影響すると思われる．本分類は肖折線が関節面にに 及ぶか否かで分類してありその考えに令致する。

質 問浜の町病院 森久誉八郎 強固な固足という事ですが，固足材料がいくら強く ても，顆部为のものは，非常に翉い部分である，従っ て, 本当に強固な固蓗が得られるとは考えられないが, この点どの様に考えられますか？

回答博慈会記念病院 松藤 靖 修復を可及的に整えれば，固分材料は決して強くな くても，早期より動かしても偽関節による事はまず無 いと考えます。 